\title{
Carbon dioxide fluxes across the Sierra de Guadarrama, Spain
}

\author{
R. Inclán · C. Uribe ' D. De La Torre · D. M. Sánchez • \\ M. A. Clavero $\cdot$ A. M. Fernández $\cdot$ R. Morante • \\ A. Cardeña $\cdot$ M. Fernández $\cdot$ A. Rubio
}

\begin{abstract}
Understanding the spatial and temporal variation in soil respiration within small geographic areas is essential to accurately assess the carbon budget on a global scale. In this study, we investigated the factors controlling soil respiration in an altitudinal gradient in a southern Mediterranean mixed pine-oak forest ecosystem in the north face of the Sierra de Guadarrama in Spain. Soil respiration was measured in five Pinus sylvestris L. plots over a period of 1 year by means of a closed dynamic system (LI-COR 6400). Soil temperature and water content were measured at the same time as soil respiration. Other soil physico-chemical and microbiological properties were measured during the study. Measured soil respiration ranged from 6.8 to $1.4 \mu \mathrm{mol} \mathrm{m} \mathrm{m}^{-2} \mathrm{~s}^{-1}$, showing the highest values at plots situated at higher elevation. $Q_{10}$ values ranged between 1.30 and 2.04 , while $R_{10}$ values ranged between 2.0 and 3.6. The results indicate that the seasonal variation of soil respiration was mainly controlled by soil temperature and moisture. Among siles, soil carbon and nitrogen stocks regulate soil respiration in addition to soil
\end{abstract}

temperature and moisture. Our results suggest that application of standard models to estimate soil respiration for small geographic areas may not be adequate unless other factors are considered in addition to soil temperature.

Keywords Soil respiration - Microbial biomass carbon . Carbon and nitrogen stocks - Soil water content .

Soil temperature $\cdot$ Pinus sylvestris - Altitudinal transects

\section{Introduction}

The characterization of soil respiration (SR) response through time and space is increasingly important to identify dominant sources and sinks of carbon (C) and parameterize carbon cycling to represent forest-atmosphere interactions in global modelling studios (Cox et al. 2000; Goh 2004). In the last decade, major efforts have been made to understand the environmental drivers of soil respiration. Soil temperature (ST) and soil moisture (SM) explain most of the variation in this parameter (Davidson et al. 1998; Rey et al. 2002), but additional factors such as forest type, soil fertility, soil texture, stand age, plant photosynthetic activity and topography also affect soil respiration in forested ecosystems (Rodeghiero and Cescatti 2005; Dilustro et al. 2005; Tang et al. 2005a; Kang et al. 2003).

However, the identification of the environmental factors controlling the variability of SR still remains a difficult task surrounded by large uncertainties, especially for forest soil in mountainous regions and when it is necessary to consider the effects of disturbances associated with forest fires. This is of major relevance in the Mediterranean forest ecosystems that are highly vulnerable to climate change. Numerous studies along elevation gradients indicate that soil $\mathrm{C}$ concentrations or stocks increase with altitude in 
mountainous terrains (Rodeghiero and Cescatti 2005: Garten and Hanson 2006). Field studies in the mountains of more arid areas indicate that soil moisture is an important factor controlling soil $\mathrm{C}$ stocks and fluxes in elevation gradients (Wang et al. 2000; Li et al. 2007). Topographyinduced microclimates can affect SR rates by constraining microclimatic factors, such as soil temperature and moisture (Kang et al. 2003: Li et al. 2007). Other studies suggest that several chemical and biological factors such as nitrogen $(\mathrm{N})$ and $\mathrm{C}$ dynamics co-varying with soil moisture regulate the spatial distribution of soil $\mathrm{C}$ losses through decomposition (Garten and Hanson 2006).

The purpose of this study was to investigate the main factors that control seasonal and spatial variation of soil respiration along an elevation gradient in the northern face of the Sierra de Guadarrama mountains (central Spain).

\section{Materials and methods}

Snidy site

The study took place in central Spain (Valsaín. Segovia), located in the northern face of the Sierra de Guadarrama $\left(40^{\circ} 51^{\prime} \mathrm{N}, 4^{\circ} 3^{\prime} \mathrm{W}\right)$. The total area of the Valsaín forest is 10.672 ha, covered mainly by Scots pine (Pinus sylvestris L.). Other species present include oak (Quercus pyrenaica Willd.) and montane broom (Cytisus purgans (L.) Boiss.), with small areas of Holm oak (Quercus ilex subsp. ballota (Desf.) Samp.) and riparian forest. The herbaceous layer is largely made up of grasses. which develop in spring. dry off in summer and regrow to some extent after the first autumn rains.

The climate is nemoro-Mediterranean. The rainfall distribution is irregular, with a drought period in summer of approximately 2 months and an annual average rainfall of $1,600-1.400 \mathrm{~mm}$. Mean temperatures range between 1.5 and $2.7^{\circ} \mathrm{C}$ during winter and 19.7 and $20.3^{\circ} \mathrm{C}$ during summer. Geologically, granites are predominant. Soils are classified as Humic Cambisols or Typic Haplumbrepts.

\section{Experimental design}

A transect was established in a 64 ha $P$. sylvestris $\mathrm{L}$. watershed spread along an elevation gradient ranging from 1.320 to $1.592 \mathrm{~m}$ asl. Four sampling plots with dimensions $10 \mathrm{~m} \times 15 \mathrm{~m}$ were designated within the experimental site. An additional site (plot 100) was selected at a higher elevation $(1,700 \mathrm{~m}$ asl), an area that was burned 2 years previously (Table 1). The tree density was 220 tree/ha. with a mean height of $30 \mathrm{~m}$ and a mean diameter at breast height of $41 \mathrm{~cm}$. The mean age of the stands was 120 years. The general aspect of the site was NE with a mean slope of $30 \%$.
The leaf area index (LAI) was $6.42 \mathrm{~m}^{2} \mathrm{~m}^{-2}$. The historical meteorological data collected in the area found that temperature decreased by about $0.65^{\circ} \mathrm{C}$ for every $100 \mathrm{~m}$ and annual precipitation increased by about $100 \mathrm{~mm}$ for every $100 \mathrm{~m}$ (Lopez Arias M, personal communication). A summary of the site characteristics is given in Table 1.

Air temperature and precipitation during the experimental period were obtained from the weather station in Puerto de Navacerrada (1.860 m asl; Fig. 1).

Soil respiration. temperature and moisture measurements

Measurements of SR. ST and SM were conducted between spring 2005 and summer 2006 randomly in each forest plot on a monthly basis, using a closed dynamic system LI- 6400 coupled to an LI-6400-9 soil chamber (LI-COR inc., Lincoln, NE. USA). Measurements were made between 10:00 a.m. and 16:00 p.m. to minimize the diurnal variation in soil respiration using PVC collars ( $10 \mathrm{~cm}$ diameter and $4.5 \mathrm{~cm}$ length), which were inserted into the soil at $2.5 \mathrm{~cm}$ depth (to avoid root severing), at least 1 week prior to investigation, and left in place throughout the course of the experiment. The measurement of SR consisted of placing the chamber on the collar, scrubbing the $\mathrm{CO}_{2}$ to sub-ambient levels and measuring the flux rate as it rose from $15 \mathrm{ppm}$ below to $15 \mathrm{ppm}$ above the atmospheric value. Soil respiration sampling was not performed on days following a rain event to avoid an overestimation of the efflux due to $\mathrm{CO}_{2}$ displacement from soil pores (Rey et al. 2002). A total of 12 collars were placed in plots 14,22 and 42 ; whereas 9 collars were employed in plot 33 and 6 in plot 100 .

Soil moisture content and soil temperature in the top $10 \mathrm{~cm}$ of soil were measured next to each soil respiration measurements with a time-domain reflectometry system (TRIMEGM. IMKO GmbH. Etclingen. Germany) and a thermocouple sensor (Omega Engineering. Stamford, CT). Soil water content was measured at three points around each collar.

\section{Soil properties}

\section{Soil sampling}

In March 2006. soil samples were taken from three different sites in each plot. Five soil cores were extracted $(10 \mathrm{~cm}$ deep $\times 8 \mathrm{~cm}$ diameter) beneath the organic layer and composited. Soils were kept separately in plastic bags and rapidly transported on ice in a dark cooler to the laboratory and stored in a refrigerator $\left(4^{\circ} \mathrm{C}\right)$ prior to the sampling process.

Composite mineral samples were separated into two subsamples for the determination of physico-chemical and 
Table 1 Summary of site characteristics of six study plots spread along an altitudinal gradient in a Pinus sylvestris $\mathbf{L}$. forest in the northern Sienra de Guadarrama mountains

\begin{tabular}{|c|c|c|c|c|c|}
\hline & Plot 14 & Plot 22 & Plot 33 & Plot 42 & Plot 100 \\
\hline Latitude $(\mathrm{N}$, deg. $)$ & $40^{\circ} 50^{\prime} 58^{\prime \prime}$ & $40^{\circ} 50^{\prime} 39^{\prime r}$ & $40^{\circ} 50^{\prime} 59^{\prime r}$ & $40^{\circ} 51^{t} 15^{t r}$ & $40^{\circ} 49^{\prime} 15^{\prime r}$ \\
\hline Longitude ( $\mathrm{W}$, deg.) & $4^{\circ} 02^{\prime} 52^{\prime \prime}$ & $4^{\circ} 02^{\prime} 52^{\prime \prime}$ & $4^{\circ} 02^{\prime} 52^{\prime \prime}$ & $4^{\circ} 02^{\prime} 34^{\prime \prime}$ & $4^{\circ} 04^{\prime} 2^{\prime \prime}$ \\
\hline Elevation (masl) & 1.592 & 1.579 & 1.380 & 1,320 & 1.700 \\
\hline Slope (\%) & 22 & 50 & 20 & 67 & 49 \\
\hline Aspect (deg) & $30^{\circ} \mathrm{NNE}$ & $100^{\circ} \mathrm{ESE}$ & $60^{\circ} \mathrm{NE}$ & $110^{\circ} \mathrm{ESE}$ & - \\
\hline \multirow[t]{2}{*}{ Total porosity (\%) } & 62 & 61 & 55 & 64 & 67 \\
\hline & b & b & $c$ & ab & a \\
\hline \multirow[t]{2}{*}{ Particle density $\left(\mathrm{g} / \mathrm{cm}^{3}\right)$} & 2.57 & 2.64 & 2.63 & 2.64 & 2.54 \\
\hline & b & a & $a$ & a & $\mathrm{c}$ \\
\hline \multirow[t]{2}{*}{ WFP (\%) } & 58.4 & 50.5 & 51.9 & 45.0 & 28.8 \\
\hline & a & ab & $a b$ & $\mathbf{b}$ & $\mathrm{c}$ \\
\hline \multirow[t]{2}{*}{$\mathrm{pH}(1: 2)$} & 5.6 & 5.8 & 5.8 & 5.7 & 5.4 \\
\hline & b & a & $\mathbf{a}$ & $a b$ & c \\
\hline \multirow[t]{2}{*}{$\mathrm{EC}(\mu \mathrm{S} / \mathrm{cm})$} & 171 & 156 & 119 & 164 & 216 \\
\hline & $a b$ & bc & $\mathrm{c}$ & $b c$ & $\mathbf{a}$ \\
\hline \multirow[t]{2}{*}{ C STOCKS $\left(\mathrm{kg} C \cdot \mathrm{m}^{-2}\right)$} & $5.57 \pm 0.16$ & $7.76 \pm 0.20$ & $7.37 \pm 0.30$ & $5.34 \pm 0.27$ & $7.06 \pm 0.30$ \\
\hline & $\mathrm{b}$ & $\mathbf{a}$ & a & b & a \\
\hline \multirow[t]{2}{*}{ N STOCKS $\left(\mathrm{kg} \mathrm{N} \cdot \mathrm{m}^{-2}\right)$} & $0.30 \pm 0.01$ & $0.34 \pm 0.003$ & $0.38 \pm 0.01$ & $0.27 \pm 0.006$ & $0.42 \pm 0.02$ \\
\hline & $\mathrm{c}$ & $b c$ & $a b$ & $\mathrm{c}$ & a \\
\hline \multirow[t]{2}{*}{$\mathrm{C} / \mathrm{N}$} & $18.7 \pm 0.4$ & $23.1 \pm 0.7$ & $19.3 \pm 1.4$ & $19.4 \pm 1.1$ & $16.9 \pm 0.2$ \\
\hline & b & a & $a b$ & ab & b \\
\hline \multirow[t]{2}{*}{ TOC $(\mathrm{g} / \mathrm{kg})$} & $56.8 \pm 1.6$ & $75.3 \pm 2.0$ & $62.8 \pm 2.6$ & $56.8 \pm 2.9$ & $86.1 \pm 3.6$ \\
\hline & b & a & b & b & a \\
\hline \multirow[t]{2}{*}{ C-TMB (g/kg) } & $1.30 \pm 0.23$ & $1.14 \pm 0.02$ & $0.71 \pm 0.05$ & $0.60 \pm 0.05$ & $0.18 \pm 0.008$ \\
\hline & a & $a b$ & bc & ed & d \\
\hline
\end{tabular}

Means with different letters within the site are significantly different, using Tukey's HSD at the 0.05 level

Fig. 1 Precipitation and mean temperature recorded during the experimental period. Data were obtained from the weather station in Puerto de Navacerrada located approximately $2 \mathrm{~km}$ from the site of the study

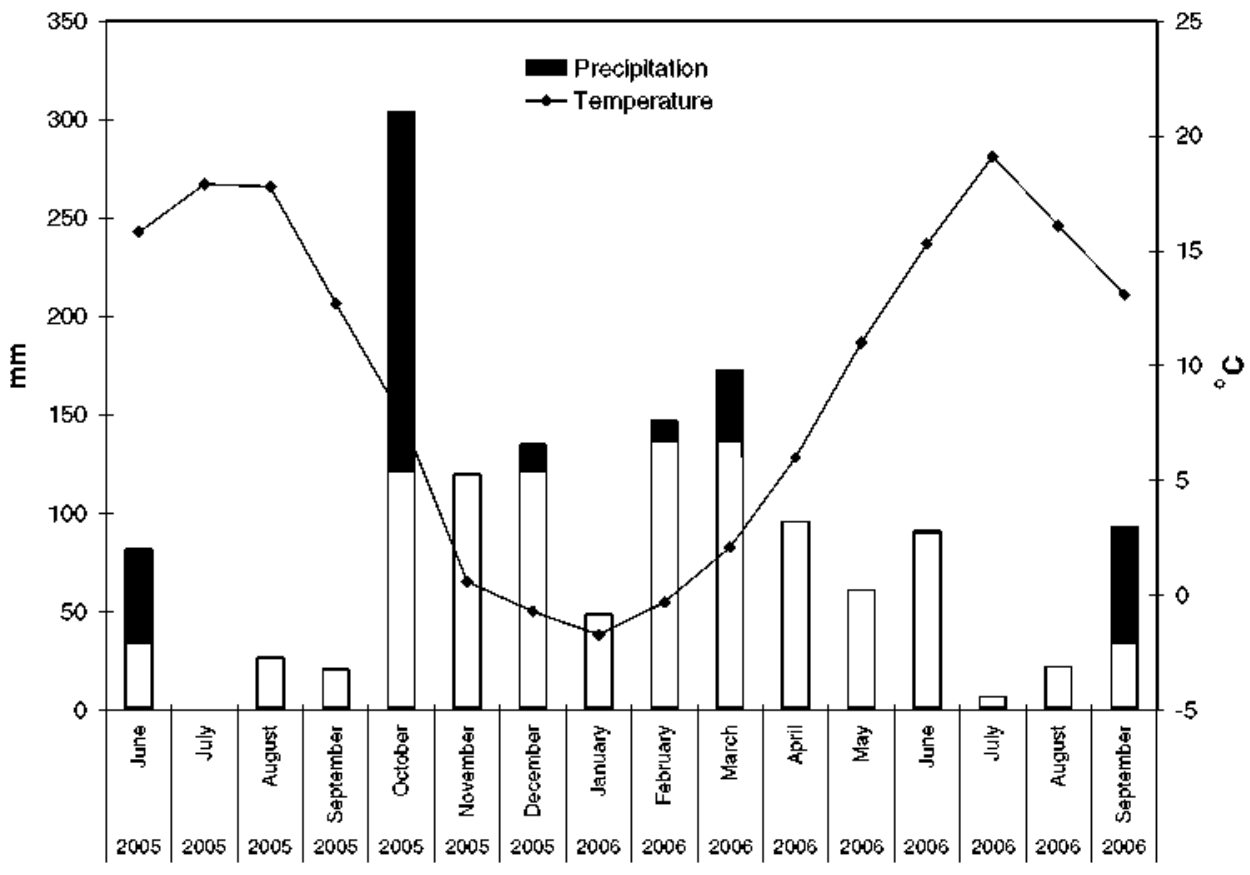


biological soil properties. The subsample for biological properties was sieved through a $2 \mathrm{~mm}$ mesh and stored at $4^{\circ} \mathrm{C}$ until they were processed. The remaining sample was air dried at room temperanure for 2-3 days and sieved through a $2 \mathrm{~mm}$ sieve to remove stones, gravel and coarse debris. Soil passing the $2 \mathrm{~mm}$ sieve was grounded and homogenized using a mortar and stored in an airtight bottle prior to determining the physico-chemical properties.

\section{Analysis of soils}

Soil $\mathrm{pH}$ and electrical conductivity (EC) were measured in a 1:2 aqueous extract. The $\mathrm{pH}$ was measured by means of an ORION $720 \mathrm{~A} \mathrm{pH}$-meter. Electrical conductivity measurements were performed by means of an ORION 115 conductimeter. The total $\mathrm{C}$ and $\mathrm{N}$ analyses were carried out by using a LECO TruSpec analyser. The organic carbon was analysed with a TOC- $\mathrm{V}_{\mathrm{CSH}}$ analyser (SHIMADZU, Shimadzu Scientific Instruments, Kyoto, Japan).

Soil moisture content (SM) and dry density values were determined on separate and unaltered core samples taken at $50 \mathrm{~mm}$ depth using standard core steel samplers $(28.5 \mathrm{~mm}$ internal diameter and $34.3 \mathrm{~mm}$ height). Soil bulk dry density was calculated from the dimensions of the samplers. taking into account the oven-dried weight as the known volume of soil. The soil moisture content or gravimetric water content was defined as the ratio of the weight of water and the weight of dry soil expressed as a percentage. The weight of water was determined as the difference between the weight of the sample and its weight after oven drying at $110^{\circ} \mathrm{C}$ for $24 \mathrm{~h}$ (UNE Standard 103300-93). Water filling porosity (WFP) was calculated as: $\mathrm{WFP}=\left(\right.$ w.c. $\left.\times \gamma_{\mathrm{s}}\right) /\left(1-\left(\rho_{\mathrm{d}} / \gamma_{\mathrm{s}}\right)\right)$, where, w.c. is the gravimetric water content, $\gamma_{s}$ is the soil particle density and $\rho_{\mathrm{d}}$ is the bulk dry density. The particle density or grain density was measured on a powdered oven-dried specimen using the pycnometer's method with water (UNE Standard 103-302).

Soil microbial biomass carbon was determined by microwave irradiation extraction method (Islam and Weil 1998). The organic carbon in the extracts of the control and microwaved soil were analysed with $T O C-\mathrm{V}_{\mathrm{CSH}}$ analyser (SHIMADZU. Shimadzu Scientific Instruments, Kyoto, Japan). The total microbial biomass $\left(\mathrm{C}_{\mathrm{TMB}}\right)$ was calculated as:

$\mathrm{C}_{\mathrm{TMB}}=\mathrm{C}_{\mathrm{EXTMW}} / 0.213$

where $C_{\text {EXTMw }}$ is the net flush of $C$, obtained from the difference between the extracted $\mathrm{C}$ in microwaved soil samples minus the extracted $\mathrm{C}$ in control soil samples, and 0.213 is a constant to compensate the fraction of extracted carbon by $0.5 \mathrm{M} \mathrm{K}_{2} \mathrm{SO}_{4}$.
Calculation of soil carbon and nitrogen stocks

Carbon and $\mathrm{N}$ pools (or stocks) in the top $10 \mathrm{~cm}$ of mineral soil $\left(\mathrm{kg} \mathrm{m}^{-2}\right)$ were estimated by multiplying values of percent $\mathrm{C}$ and $\mathrm{N}$ in the mineral soil by soil-bulk density measurements from each plot.

Statistical analysis and modelling

Plot-level seasonal temperature response of SR was calculated by means of a $Q_{10}$ function as mentioned by Janssens and Pilegaard (2003), which is called temperature sensitivity of SR:

$\mathrm{SR}=R_{10} \times Q_{10}^{((T-10) / 10)}$,

where SR ( $\mu \mathrm{mol} \mathrm{CO}_{2} \cdot \mathrm{m}^{-2} \mathrm{~s}^{-1}$ ) is the soil respiration flux, $R_{10}$ is the simulated SR at a soil temperature of $10^{\circ} \mathrm{C}$, which is often used to compare the SR characteristics of ecosystems, $Q_{10}$ is the temperature sensitivity of SR (the respiratory flux at one temperature over the flux at a temperature $10^{\circ} \mathrm{C}$ lower), and $T$ is the measured soil temperature $\left({ }^{\circ} \mathrm{C}\right)$. The functions were fitted to the measured data by means of a nonlinear least square fitter (Sigma Plot 6.0).

All statistical analyses were performed using the Statistica 6.0 software package (StatSoft. Inc., Tulsa. USA). Site (plot) and time effects for soil respiration. soil temperature and soil moisture were tested with a repeated measures analysis of variance (ANOVA). One-way analysis of variance was used to test for the effects of stand on soil respiration in the sites where there was no complete set of data available and to analyse the differences in soil properties between plots. The normal distribution and homogeneous variance were tested by the KolmogorovSmirnov and Levene's tests, respectively. Post hoc comparisons were tested using Tukey's HSD test, calculated at the $5 \%$ level. Whenever necessary, data were transformed as $(x+1)^{0.5}$ or $\log x$. Correlation analyses from the data of the entire data set were used to examine the relationship between soil respiration rates and soil properties.

\section{Results}

Soil respiration

Soil respiration values during the experimental period (June 2005-July 2006: Fig. 2) varied from $6.8 \pm 0.2$ $\mu \mathrm{mol} \mathrm{m} \mathrm{m}^{-2} \mathrm{~s}^{-1}$ in June 2005 to $1.4 \pm 0.1 \mu \mathrm{mol} \mathrm{m} \mathrm{m}^{-2} \mathrm{~s}^{-1}$ in February 2006 . Soil respiration across the six study sites showed a typical seasonal pattern with maximums in spring and summer and minimums in winter. Seasonal patterns 

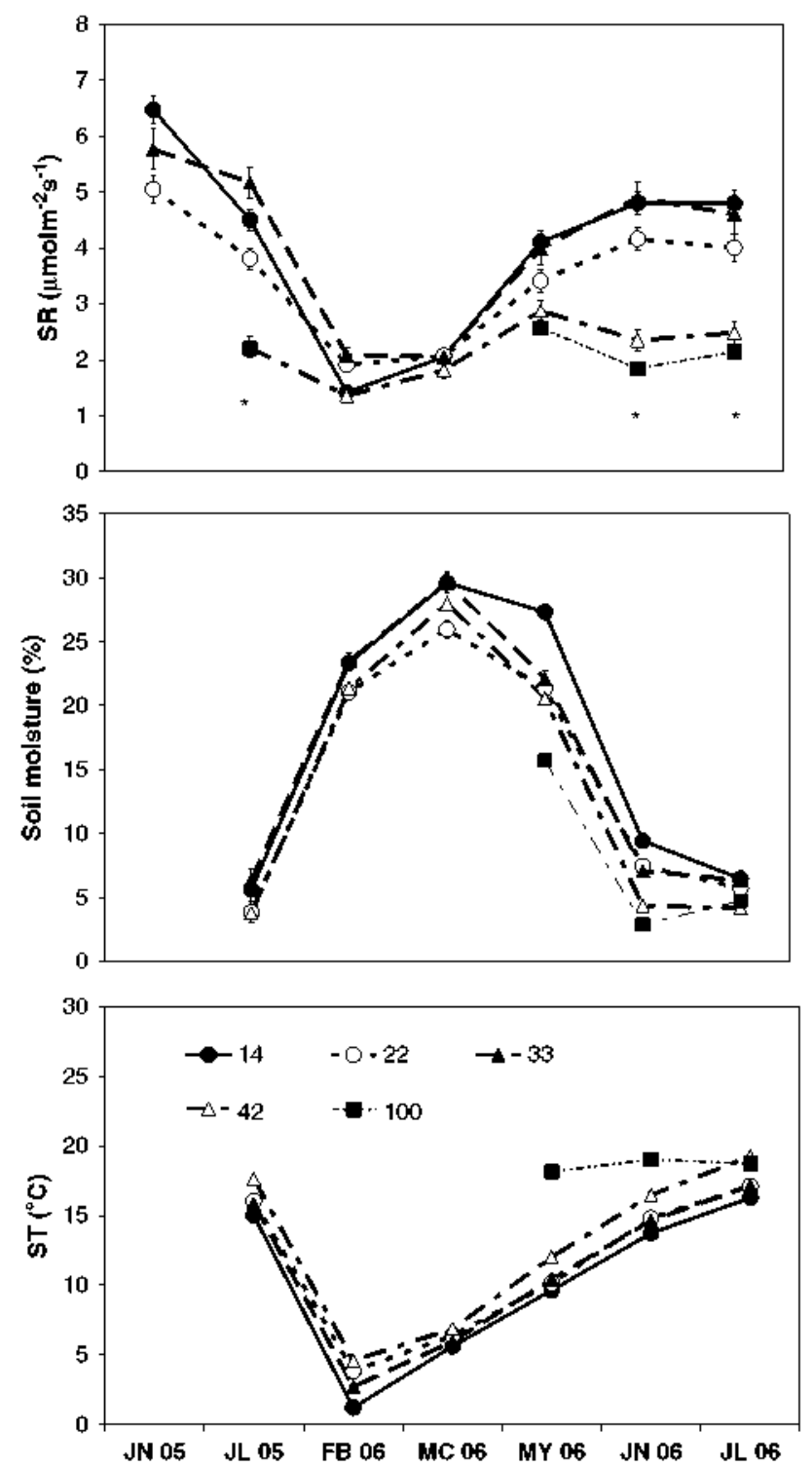

Fig. 2 Seasonal variations of observed soil respiration (SR, $\mu \mathrm{mol} \mathrm{m} \mathrm{m}^{-2} \mathrm{~s}^{-1}$ ), volumetric water content (SM, \%), soil temperature at $10 \mathrm{~cm}$ soil depth $\left(S T,{ }^{\circ} \mathrm{C}\right)$ for study plots in Valsain during the period 2005-2006. Asterisk indicates significant differences at the 0.05 level

were similar in the different plots, although temporal fluctuations were more limited in plots 42 and 100 .

Repeated measures analysis of variance indicated that SR was different among sites $\left(F_{3,131}=31,871: P=0.0\right)$ and time of the year $\left(F_{5,655}=205,29 ; P=0.0\right)$. Mean values in plot 22 were intermediate $(P<0.05)$ between the highest values of plots 14 and 33 and the lowest values of plot 42 during July 2005. June 2006 and July 2006. Plot 100 showed low values $(P<0.05)$, similar to those found in plot 42, and significantly different from the rest of the plots.
Soil temperature and moisture

Both soil temperature and moisture content varied according to the season. Maximum soil temperature coincided with minimum soil moisture during the summer. and minimum soil temperatures were recorded in winter when soil moisture was highest (Fig. 2).

Soil temperature varied with site $(P=0.0)$, time $(P=0.0)$ and site over time $(P=0.0)$. There was a significant site effect $(P<0.05)$, with plot 42 exhibiting the highest soil temperature followed by plot 22,33 and finally 14. Soil temperature was highest in July 2006 , declined in June 2005, followed by May 2006 and March 2006, and dropped to a minimum in February 2006. Plot 100 showed the highest values during May 2006 and June 2006.

Soil moisture differed over time $(P=0.0)$. site $(P=0.0)$ and site over time $(P=0.0)$. Soil moisture was highest $(P<0.05)$ in plots 14 and 33 and lowest in plots 22 and 42 . Soil moisture during May 2006 was higher $(P<0.05)$ in plot 14 , while no significant difference was observed among the other plots. During June 2006, soil moisture was higher in plot 14 than in plot 42 . For all treatments, soil moisture rose to a maximun in winter and spring months and declined steadily through June to a minimum in July.

Influence of temperantre and moisture on soil respiration

Not surprisingly, both soil temperature and moisture were highly significant in a regression analysis explaining a large percentage of the seasonal variability in soil respiration. Soil moisture showed significant negative correlations to seasonal soil respiration for plot $14\left(r^{2}=0.28, r=-0.53\right.$, $P=0.0)$, plot $22\left(r^{2}=0.39, r=-0.63, P=0.0\right)$, plot 33 $\left(r^{2}=0.36, r=-0.60, P=0.0\right)$ and plot $42\left(r^{2}=0.06\right.$. $r=-0.25, P=0.0$ ); while positive correlations were associated with plot $100\left(r^{2}=0.10, r=0.32 . P=0.0\right)$. Soil respiration was satisfactorily represented as a function of temperature. using the $Q_{10}$-type model fitted to the entire data set (Fig. 3). In plot 100, soil respiration and soil temperature were not correlated. The temperature-based $Q_{10}$ models had similar $Q_{10}$ values ranging between 1.30 and 2.04 . The $R_{10}$ values ranged between 2.0 and 3.61 .

In plots 33 and 42 , an interaction between soil temperature and soil moisture explained a 40 and $36 \%$ of the variability, respectively (Table 2 ).

\section{Influence of soil parameters on soil respiration}

Soil carbon stocks varied between $5.57 \pm 0.2 \mathrm{~kg} \mathrm{~m}^{-2}$ (plot 14) and $7.76 \pm 0.2 \mathrm{~kg} \mathrm{~m}^{-2}$ (plot 22), while soil nitrogen content varied from $0.27 \pm 0.01 \mathrm{~kg} \mathrm{~m}^{-2}$ (plot 42) to $0.42 \pm 0.02 \mathrm{~kg} \mathrm{~m}^{-2}$ (in plot 100; Table 1). Regarding 
Fig. 3 Soil $\mathrm{CO}_{2}$ efflux versus soil temperature as measured in Spanish Scots pine forest. The solid line represents the best fitting $Q_{10}$ function. Functions were fitted through the entire data set. $R^{2}$ represents the proportion of variability in soil respiration explained by soil temperature
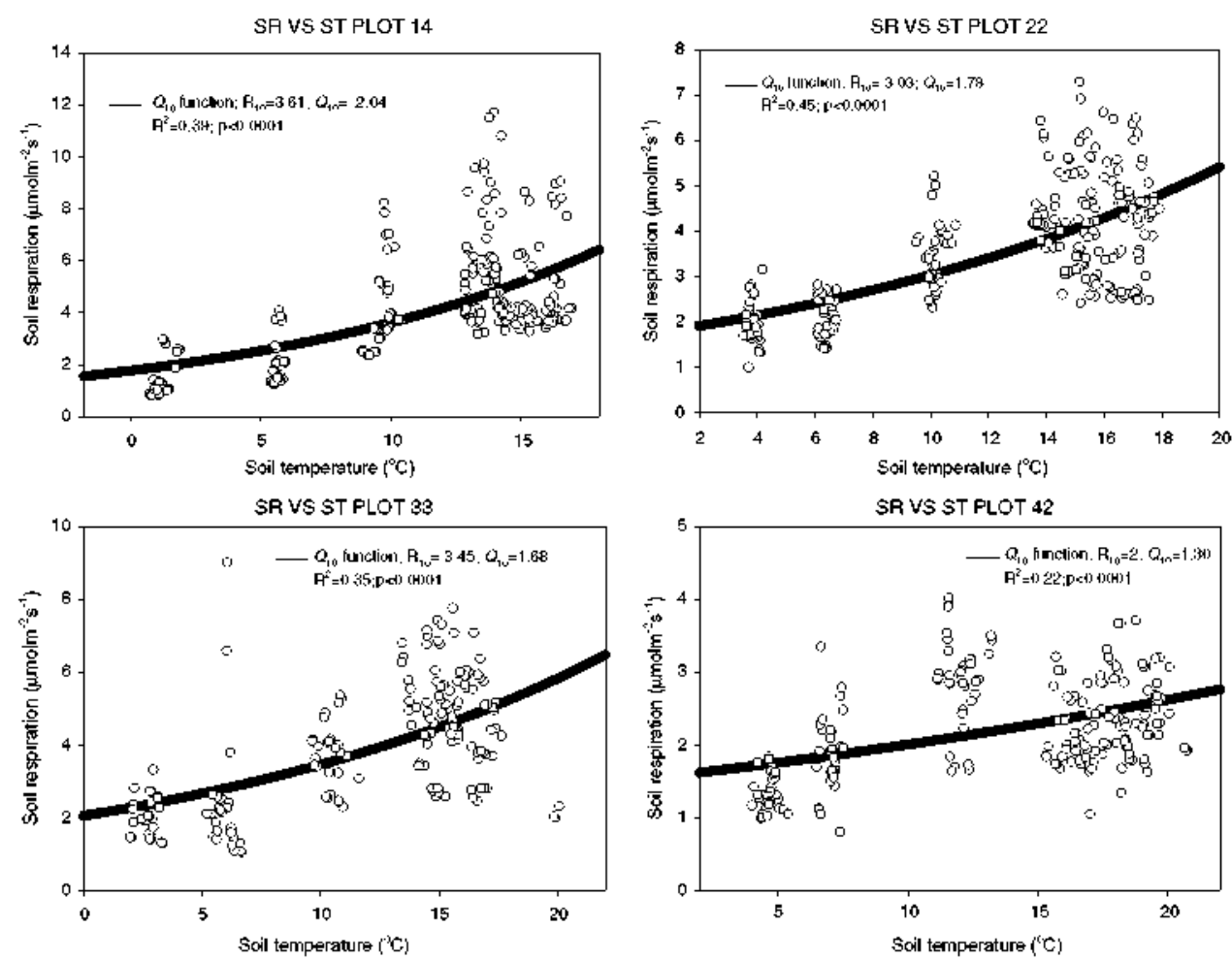

Table 2 Soil respiration as a function of temperature and moisture content, using a fitted linear curve through the entire data set

\begin{tabular}{llll}
\hline & Model & $r^{2}$ & $P$ \\
\hline Plot 33 & SR $=3.02+0.13 \times \mathrm{ST}-0.04 \times \mathrm{SM}$ & 0.40 & 0.0 \\
Plot 42 & SR $=-0.19+0.13 \times \mathrm{ST}+0.04 \times \mathrm{SM}$ & 0.35 & 0.0 \\
\hline
\end{tabular}

microbial biomass carbon (C-TMB), plot 14 showed the highest content, while the burned plot (plot 100) had the lowest. Soil respiration (Table 3 ) was positively correlated with $\mathrm{C}$ and $\mathrm{N}$ stocks and WFP, and negatively correlated to total porosity. Although not significantly, soil respiration tends to increase with $\mathrm{C}-\mathrm{TMB}, \mathrm{TOC}, \mathrm{pH}$ and $\mathrm{C} / \mathrm{N}$.

\section{Discussion and conclusions}

The values of soil respiration in this area are in a range comparable with those measured in other Mediterranean forests (Rey et al. 2002: Rodeghiero and Cescatti 2005; Tedeschi et al. 2006). The annual $Q_{10}$ derived from the data set were lower than the global median of 2.4 (Raich and Schlesinger 1992) and the range data $(2.0-6.3)$ reported for forest ecosystems (Janssens et al. 2003). Our estimates of $R_{l 0}(2.0-3.6)$ are in agreement with the range $(0.7-$ $4.9 \mu \mathrm{mol} \mathrm{m}^{-2} \mathrm{~s}^{-1}$ ) observed in European forests (Janssens et al. 2003). We found similar $Q_{10}$ and $R_{10}$ values as were observed by Tang et al. $2005 \mathrm{~b}$ and Rodeghiero and Cescatti 2005 in Mediterranean ecosystems. The reasons for reduced temperature sensitivity in Valsain forest are unclear. and depend on the environmental constraints (generally low soil moisture content) and the substrate.

The results indicate that SR seasonal variation was mainly dominated by ST (Fig. 3) and that soil moisture also had an important influence on SR. However, the influence of SM on SR depends on the site. In plot 100. the temporal variation in SR was mainly controlled by soil moisture, and in plots 33 and 42 the interaction between ST and SM explained most of the variability observed. Although it is difficult to separate completely the influence of ST and SM imposed on SR, our short-term observation showed that SR responded mainly to ST in winter and that the interaction of soil temperature and moisture on SR was especially apparent during the summer months when low soil moisture limited soil microbial activity and root growth despite warm soil temperature (Fig. 2).

In the Valsain mountains, in situ measurements of soil respiration decline with declining altitude in contrast with other field studies that indicate correlations between SR and elevation (Wang et al. 2000; Rodeghiero and Cescatti 2005; Garten and Hanson 2006). Whereas the warmest temperatures were associated with the lowest elevation site (plot 42), the highest rates of SR were observed at the highest elevation plots (14.22 and 33). The elevation factor alone may not explain the SR sensitivity by itself. Topography produces spatially heterogeneous SM and thus soil respiration. In our study, more mesic north-facing slopes (plot 14 and 33) showed higher SR relative to less 
Table 3 Correlation coefficients between various soil variables and soil respiration (SR, $\mu \mathrm{mol} \mathrm{m} \mathrm{m}^{-2} \mathrm{~s}^{-1}$ ) at March 2006 in Pinus sylvestris $\mathrm{L}$. forest in the Sierra de Guadarrama

\begin{tabular}{lllllllllll}
\hline & $\begin{array}{l}\text { C.stacks } \\
\left(\mathrm{kg} \cdot \mathrm{C} \cdot \mathrm{m}^{-2}\right)\end{array}$ & $\begin{array}{l}\text { N.stocks } \\
\left(\mathrm{kg} \cdot \mathrm{N} \cdot \mathrm{m}^{-2}\right)\end{array}$ & C/N & $\begin{array}{l}\text { C-TMB } \\
\left(\mathrm{g} \cdot \mathrm{kg}^{-1}\right)\end{array}$ & $\begin{array}{l}\text { TOC } \\
\left(\mathrm{g} \cdot \mathrm{kg}^{-1}\right)\end{array}$ & $\begin{array}{l}\text { Particle density } \\
\left(\mathrm{g} \cdot \mathrm{cm}^{-3}\right)\end{array}$ & $\begin{array}{l}\text { Total porosity } \\
(\%)\end{array}$ & $\begin{array}{l}\text { WFP } \\
(\%)\end{array}$ & $\begin{array}{l}\text { pH } \\
(1: 2)\end{array}$ & $\begin{array}{l}\text { EC } \\
\left(\mu \mathrm{S} \cdot \mathrm{cm}^{-1}\right)\end{array}$ \\
\hline $\mathrm{SR}$ & $\mathbf{0 . 6 5}$ & $\mathbf{0 . 6 5}$ & 0.20 & 0.28 & 0.39 & 0.06 & $-\mathbf{0 . 6 9}$ & $\mathbf{0 . 6 8}$ & 0.48 & -0.50 \\
$Q_{10}$ & 0.32 & 0.35 & 0.06 & $\mathbf{0 . 8 6}$ & 0.26 & $-\mathbf{0 . 6 4}$ & -0.18 & $\mathbf{0 . 8 0}$ & -0.30 & 0.19 \\
$R_{10}$ & 0.42 & 0.53 & 0.04 & 0.52 & 0.21 & -0.53 & -0.49 & $\mathbf{0 . 7 2}$ & -0.14 & -0.15 \\
\hline
\end{tabular}

Bold numbers indicate a significant correlation at $P<0.05$

mesic south-facing slopes (plot 22 and 42) despite higher ST at south-facing slopes.

The role of temperature and soil moisture in SR under field conditions is not always straightforward and my be influenced by vegetation covers. litter chemistry and thickness, soil organic matter, variable rates of belowground root growth and activity. $\mathrm{N}$ availability and soil characteristics. All these factors potentially interact in complex ways through effects on decomposition. In our experiment, we obtained SR, $Q_{10}$ and $R_{10}$ values higher in the cooler, wetter site relative to the warmer. drier site. This is in agreement with Xu and Qi (2001). If we compare this trend with C-TMB (decrease in the same way), we could explain this behaviour by a faster response of the microbial community to warming when easily degradable substrate ability is also high.

In our experiment, the positive correlations between SR, $Q_{t o}$ and $R_{t o}$ values and $\mathrm{C}$ and $\mathrm{N}$ stocks. TOC. C-TMB and WFP (Table 3) indicated that microbial substrate quantity and nitrogen-rich conditions promote higher $Q_{10}$ and SR values.

Atmospheric deposition and litter fall inputs could influence SR along the altitudinal transect.

Prior studies along the elevation gradient in Valsaín indicated a decline in litter fall inputs and $\mathrm{N}$ deposition with decreasing altitude (González Cascón et al. 1994: Garcia del Barrio et al. 1997). At low elevations, both higher mean annual temperatures and lower site $\mathrm{N}$ availability potentially contribute to lower soil $\mathrm{C}$ stocks and shorter turnover time for labile soil $\mathrm{C}$. The highest values of SR in plot 14 also could be related to higher pine density and regeneration in this plot, and to differences in root respiration. Results from studies of other forests indicate that fine root biomass is directly associated with tree basal area (Chen et al. 2004).

Our results reveal that fire can alter the level of $\mathrm{C}, \mathrm{N}$, $\mathrm{pH}$, and C-TMB in the soil. The increases in C concentration during the first years after the fire could be attributed to unburnt remains from dead roots, which slowly incorporate into the soil. $\mathrm{C} / \mathrm{N}$ ratios were lower in the burnt soils than in the unburnt soils. Alteration of nitrogen by fire is a complex process. Fire alters the amount of nitrogen in the soil by volatilization of some into the atmosphere and by converting the nitrogen into different nitrogen compounds. The $\mathrm{pH}$ decreased after the fire. The burnt plot exhibited reduced microbial biomass $\mathrm{C}$ compared to manire plots. This data revealed that fire altered the microbial diversity of the soil ecosystem. After the fire, C-TMB was very low, which indicates that microbial diversity had decreased significantly even 2 years after the occurrence of the disturbance. Decreases in microbial biomass have been widely reported after a fire. In the burnt plot. SR, $Q_{10}$ and $R_{10}$ were lower than in unburnt plots.

From the results obtained, it can be concluded that under similar climatic conditions and soil types within a small geographical area, variation in soil temperature, soil moisture, carbon and nitrogen stocks and C-TMB can influence SR in southern Pinus sylvestris $\mathbf{L}$. forest. Thus changes in soil parameters over small scales need to be considered when modelling landscape-level SR. Furthermore, a better understanding of how natural disturbances affect $\mathrm{C}$ and $\mathrm{N}$ cycling is crucial for predicting how changes in climate and disturbance regimens will affect the exchange of $\mathrm{C}$ between forest ecosystems and the atmosphere.

Acknowledgments This research was conducted in the framework of Spanish HU2005-0023, AGL2004-01941 and CGL 2006-02922/ CLI projects and the European COST 639 (BumOut) project. The authors would like to express their gratitude to Mr. Javier Dones. Mr. Manuel Lopez Arias and Mr. Jose M. Grau for their valuable assistance with field aspects and for the data provided.

\section{References}

Chen W, Zhang Q, Chilar J, Bauhus J, Price DT (2004) Estimating fine-root biomass and production of boreal and cool temperate forests using above-ground measurements: a new approach. Plant Soil 256:31-46. doi: $10.1007 /$ s 11104-005-8503-3

Cox PM, Betts RA, Jones CD, Spall SA, Totterdell IJ (2000) Acceleration of global warming due to carbon cycle feedbacks in a coupled climate model. Nature 408(6809):184-187. doi: $10.1038 / 35041539$

Davidson EA, Belk E, Boone RD (1998) Soil water content and temperature as independent or confounded factors controlling soil respiration in a temperate mixed hardwood forest. Glob Chang Biol 4:217-227, doi: $10.1046 / j .1365-2486.1998 .00128 . x$

Dilustro JJ, Collins B, Duncan L, Crawford C (2005) Moisture and soil texture effects on soil $\mathrm{CO}_{2}$ efflux components in 
southeastern mixed pine forests. For Ecol Manage 204:85-95. doi: $10.1016 /$ j.foreco.2004.09.001

Garcia del Bario JM. Lopez Arias JM. Morales D (1997) Producción y renovación de acículas en la cubierta árborea de un pinar de Pinus sylvestris en la Sierra de Guadarrama. Valsaín. Segovia. Actas IRATI 97. II Congreso Forestal Español. Tomo I. pp 325-330

Gaten CT. Hanson PJ (2006) Measured forest soil C stocks and estimated turnover times along an elevation gradient. Geoderma 136:342-352. doi: $10.1016 / j$.geoderma.2006,03,049

Goh KM (2004) Carbon sequestration and stabilization in soils: implications for soil productivity and climate change. Soil Sci Plant Nutr 50(4):467-476

González Cascón MR, Lopez Arias M, Serrano M, Minaya MT (1994) Balance de entradas/salidas de cationes en una pequeña cuenca forestal de Pinus sylvestrís en la Sierta de Guadarrama. Ecologia 8:157-166

Istam KR, Weil RR (1998) Microwave irradiation of soil for routine measurement of microbial biomass carbon. Biol Fertil Soils 27:408-416. doi: $10.1007 / \mathrm{s} 003740050451$

Janssens IA. Dore S, Epron D et al. (2003) Climatic influences on seasonal and spatial differences in soil $\mathrm{CO}_{2}$ efflux. In: Canopy fluxes of energy, water and carbon dioxide of European forests. Springer, Berlin, pp 235-256

Janssens IA. Pilegaard K (2003) Large seasonal changes in Q10 of soil respiration in a beech forest. Glob Chang Biol 9:911-918. doi: $10.1046 / \mathrm{j} .1365-2486.2003 .00636 . \mathrm{x}$

Kang S, Doh S, Lee D, Lee D, Jin VL, Kimball JS (2003) Topographic and climatic controls on soil respiration in six temperate mixed-hardwood forest slopes, Korea. Glob Chang Biol 9:1427-1437. doi: 10.1046/j.1365-2486.2003.00668.x

Li H. Yan J, Yue X. Wang M (2007) Significance of soil temperature and moisture for soil respiration in a Chinese mountain area. Agric For Meteorol, doi:10.1016/jl.agrformet.2007,10.009
Raich JW, Schlesinger WH (1992) The global carbon dioxide flux in soil. Tellus B Chem Phys Meteorol 44B:81-99

Rey A, Pegoraro E, Tedeschi V, De Parri I, Jarvis P, Valentini R (2002) Annual variation in soil respiration and its components in a coppice oak forest in central Italy. Glob Chang Biol 8:851866. doi: $10.1046 / \mathrm{j} .1365-2486.2002 .00521 \mathrm{x}$

Rodeghiero M. Cescatti A (2005) Main determinants of forest soil respiration along an elevation/temperature gradient in the Italian Alps. Glob Chang Biol 11:1024-1041. doi:10.1111/j.1365-2486. 2005.00963.x

Tang J, Baldocchi D、 Xu L (2005a) Tree photosynthesis modulates soil respiration on a diurnal time scale. Glob Chang Biol 11:1298-1304. doi:10.1111/j.1365-2486.2005.00978.x

Tang J, Misson L, Gershenson A, Cheng W, Goldstein A (2005b) Continuous measurements of soil respiration with and without roots in a ponderosa pine plantation in the Sierra Nevada Mountains. Agric For Meteorol 132:212-227, doi:10.1016/ j.agrformet.2005.07.011

Tedeschi V, Rey A. Manca G. Valentini R, Jarvis PG, Borghetti M (2006) Soil respiration in a Mediterranean oak forest at different developmental stages after coppicing. Glob Chang Biol 12:110121. doi: $10.1111 /$ j. $1365-2486.2005 .01081 . \mathrm{x}$

Wang Y, Amundson R, Niu XF (2000) Seasonal and altitudinal variation in decomposition of soil organic matter inferred from radiocarbon measurements of soil $\mathrm{CO}_{2}$ flux. Global Biogeochem Cycles 14:199-211. doi:10.1029/1999GB900074

$\mathrm{Xu}$ M, Qi Y (2001) Soil-surface $\mathrm{CO}_{2}$ efflux and its spatial temporal variation in a young ponderosa pine plantation in northern California. Glob Chang Biol 7:667-677. doi:10.1046/j.1354$1013.2001 .00435 . x$ 